\title{
Challenges for Monetary Policy in the European Monetary Union
}

\begin{abstract}
This article was originally presented as the Homer Jones Memorial Lecture, organized by the Federal Reserve Bank of St. Louis, St. Louis, Missouri, April 13, 2011.

Federal Reserve Bank of St. Louis Review, July/August 2011, 93(4), pp. 235-42.
\end{abstract}

Axel A. Weber

F our years ago, I was invited to give a speech in Paris. Its title- "From Academic to Policy Maker"-referred to the fact that I started out as an academic (Weber, 2007). I began that speech by mentioning a number of other academics who went on to become central bankers: Mervyn King, Ben Bernanke, Janet Yellen, Bill Poole, and Otmar Issing, to name but a few.

I continued by analyzing why there are so many academics in monetary policy. James Bullard, by the way, is another case in point, whom I did not mention at the time because he was not yet in his current position. One of the main reasons why, over the past years, academic researchers have been taking up leading positions at central banks is that monetary policy itself has been heavily influenced by the findings of academic research. During the financial crisis, monetary policy and economies across the world have benefited significantly from these insights since they have helped us to swiftly apply the appropriate policy responses to contain the crisis. Conversely, the crisis has also raised important issues for academic research in monetary economics as well as in other fields.

As of next month [May 2011], after seven years as a policymaker, I shall be taking up the position of a faculty member of the University of
Chicago Booth School of Business. In spite of this upcoming transition "from policymaker to academic," my remarks on the challenges for monetary policy in the European Monetary Union (EMU) are from the policymaker's perspective.

\section{THE FINANCIAL CRISIS AND ITS LESSONS FOR MONETARY POLICY}

The financial crisis has brought the "monetary policy consensus" formed in the years prior to the crisis under scrutiny (Bean et al., 2010). The framework of monetary policy differed significantly from one central bank to another. Nevertheless, across the board their primary objective was price stability-defined as a stabilization of the inflation rate at around 2 percent across a horizon of approximately two years. Steering short-term interest rates was considered a sufficient means of achieving this target. Central bank forecasts played a key role in monetary policy decisionmaking, with monetary aggregates increasingly taking a backseat in many forecast models.

Furthermore, capital markets were mostly assumed to be efficient, meaning that financial imperfections and their potential macroeconomic

Axel A. Weber is the former president of the Deutsche Bundesbank and a visiting professor of economics at the University of Chicago Booth School of Business. This paper is based on his Homer Jones Memorial Lecture at the Federal Reserve Bank of St. Louis, April $13,2011$.

(C) 2011, The Federal Reserve Bank of St. Louis. The views expressed in this article are those of the author(s) and do not necessarily reflect the views of the Federal Reserve System, the Board of Governors, or the regional Federal Reserve Banks. Articles may be reprinted, reproduced, published, distributed, displayed, and transmitted in their entirety if copyright notice, author name(s), and full citation are included. Abstracts, synopses, and other derivative works may be made only with prior written permission of the Federal Reserve Bank of St. Louis. 
effects were not taken into account. Temporary inefficiencies, such as asset price bubbles, were considered possible, but the majority view was that monetary policy could do little to counteract such developments.

Microprudential supervision was regarded as a sufficient means of containing risks in the financial sector. Monetary policymakers should intervene only after a financial crisis had occurred, minimizing the macroeconomic damage through resolute interest rate cuts.

Even though monetary policy proved indispensable and highly successful in containing the crisis and preventing a meltdown of the financial system, events have cast doubt on this consensus. The question now is whether and to what extent monetary policy should take account of financial market developments before a crisis occurs (Deutsche Bundesbank, 2011c; also see the following section). Let me elaborate on some aspects of this in greater depth.

\section{A Stronger Role for Financial Markets in Monetary Policy Analysis...}

Given the genesis of the crisis, it is undeniable that monetary policy with too short a policy horizon can fail to take account of financial imbalances that eventually spill over to the real economy, thus jeopardizing price stability. So, how should monetary policy incorporate the experience of the crisis into its decisionmaking process?

In the pre-crisis phase, monetary policy decisions were often based on models in which the financial sector played only a minor or no role at all. Therefore, an obvious and important lesson from the crisis is that the theoretical and empirical foundations of monetary policy must place a greater emphasis on both the banking sector and financial imperfections.

As regards the Eurosystem's monetary policy strategy, the monetary pillar already contains major elements of such an approach. In the more recent past, the Eurosystem has stepped up its efforts to continually enhance its monetary analysis (Papademos and Stark, 2010). The aim is to identify irregularities in the patterns of a number of variables, since an unusual pattern in loan developments and monetary aggregates can provide valuable indications of excessive credit growth. This requires, among other things, an extension of the usual decisionmaking horizon, as financial distortions often build over a fairly long period. As a result, monetary policy should become more symmetrical over the financial cycle and can thus make a key contribution to financial stability (Weber, 2010a).

\section{...A Separate Toolkit for Financial Stability...}

However, this alone is insufficient to ensure financial stability. Until the crisis, the majority view had been that asset price bubbles are difficult to identify in a timely manner and that interest rates are too blunt a tool to burst such bubbles at an early stage. These reservations have not been invalidated by the crisis and, therefore, the debate on how to better prevent financial crises turned to the specific incentives within the financial system and the existing supervision, which focuses primarily on individual institutions, as these may have encouraged the buildup of debtfinanced imbalances. Thus, a greater emphasis should be placed on macroprudential analysis and regulation (Deutsche Bundesbank, 2011b, and Basel Committee on Banking Supervision, 2010). The aim of macroprudential policy is to contain systemic risk, thus strengthening the resilience of the financial system as a whole. This approach is designed to ensure that externalities within the financial system, notably the procyclicality and interconnectedness of financial institutions, can be addressed appropriately. ${ }^{1}$ Consequently, existing supervisory tools must be expanded or adjusted to prevent systemic risk from arising in the future and to considerably reduce the likelihood of credit and asset price bubbles.

\section{...Price Stability: Still the Primary Objective of Monetary Policy}

Against this background, monetary policy and its tools must remain focused on price stability

\footnotetext{
1 A range of tools aimed at curtailing both procyclicality and network risk is currently under discussion. See Bank for International Settlements (2010) and Galati and Moessner (2011).
} 
and should not be overburdened with other objectives. In fact, the credibility of monetary policy depends not only on the clarity of its objectives but also on transparency regarding its limitations. Adopting financial stability as an additional, independent monetary policy objective runs the risk of arousing unrealistic expectations about the effectiveness of monetary policy tools. Nevertheless, central banks as institutions may still be given the additional task of pursuing financial stability, as long as they also have the appropriate set of additional independent tools available to them. Indeed, central banks' expertise constitutes a forceful argument for them to continue to play a prominent role in analyzing and assessing financial stability. The advantage of having independent tools for price stability and financial stability is evident when there is a need for monetary and macroprudential policies to be adjusted in different ways. Nevertheless, as developments in money and financial markets are of key importance for both monetary policy and macroprudential policy, there are likely interdependencies that should be taken into account. For example, bank lending is important not only for the monetary transmission process but is also a link for macroprudential policy. This creates the opportunity for policy decisions in both spheres to complement each another, but it also harbors the danger of them counteracting each other or even canceling each other out.

There is no single answer to the question of how necessary or advantageous a coordination of policy areas would be (Committee on the Global Financial System, 2010). Recent research has provided some initial clues and corroborates the view that the inflation rate can be stabilized quite well if macroprudential policy has its own tools and works alongside monetary policy (Beau, Clerc, and Mojon, 2011, and Christensen, Meh, and Moran, 2010).

However, harmful effects with respect to inflation rate volatility can arise if monetary policymakers ignore the impact of macroprudential tools on the financial markets (see Angelini, Neri, and Panetta, 2010). If central banks make decisions regarding both macroprudential and monetary policy tools, additional fluctuations in the inflation rate compared with the monetary policy status quo can be virtually ruled out, and such fluctuations could even be reduced overall (see also Bean et al., 2010).

These preliminary results should be interpreted with caution. First, the underlying dynamic stochastic general equilibrium models only approximately reproduce the complex interactions between the real and the financial sectors. Second, such research is only in its infancy; at present, only a few models allow a simultaneous analysis of monetary and macroprudential policy (see Beau, Clerc, and Mojon, 2011). Nevertheless, the results confirm that there should be a clear allocation of objectives and tools to achieve the aims of both policies. Assuming that there will be a satisfactory exchange of information between both monetary and macroprudential policymakers in the future, the existing studies give no cause to fear that the objective of price stability must be compromised.

\section{Price Stability Should Still Be Understood to Mean Low Inflation Rates}

Even though the pre-crisis consensus regarding price stability as the primary objective of monetary policy remains valid, it can be asked whether the experience of the crisis should have implications for the specific form that the objective of price stability takes. Specifically, there have been concerns that the credible commitment to ensure a low rate of inflation might restrict the leeway for monetary policy stabilization, since in the event of massive interest rate cuts the lower bound for nominal interest rates would be hit quite quickly. Two competing approaches have been suggested to deal with this alleged shortcoming: a higher inflation target (Williams, 2009, and Blanchard, Dell'Ariccia, and Mauro, 2010) and a switch to targeting the price level or, more precisely, the price-level path. ${ }^{2}$ Neither of these two alternatives convinces me.

As regards a higher inflation target, it is not only the substantial and ongoing welfare losses accompanying a rise in the inflation target that

2 Eggertsson and Woodford (2003) already proposed price-level targeting in connection with the deflation experienced in Japan. 
argue against this proposal but also, above all, the loss of credibility for monetary policy associated with such a discretionary measure (Weber, 2010b). The resulting destabilization of inflation expectations would make it significantly more difficult for the central bank to achieve its (possibly higher) inflation target and to safeguard macroeconomic stability.

Compared with a strategy of inflation targeting, price-level targeting does offer a number of advantages, at least in theory. It opens up the option of influencing private sector inflation expectations and thus of combating deflationary risks in the event of a crisis. However, it is doubtful whether a change in the target specification in the event of acute deflationary risk would be suitable for achieving the desired positive effect on private sector inflation expectations (Walsh, 2010). A more serious problem is that a strategy of price-level targeting is associated with a few additional drawbacks compared with optimal monetary policy, casting doubt on whether such a change of strategy would be beneficial (see Deutsche Bundesbank, 2011a, and Gerberding, Gerke, and Hammermann, 2010).

All in all, this means that neither raising the inflation target nor switching to price-level targeting would be appropriate from an economic stability point of view. Instead, this problem must be tackled at its root; the existing wrong incentives and regulatory loopholes must be eliminated to render crises less likely and less severe. It is, in any case, questionable whether the leeway available to monetary policy at the lower bound of the nominal short-term money market rates actually was that limited. The effectiveness of central banks' unconventional measures during the crisis gives no cause to view the lower bound of the interest rate as a binding restriction on the effectiveness of monetary policy.

\section{PARTICULAR LESSONS FOR MONETARY POLICY IN THE EURO AREA}

All the issues I have mentioned until now concern more or less all central banks and every monetary policymaker. I now turn my focus to the particular challenges for monetary policy in the euro area. These arise from the sovereign debt crisis, which is the major challenge for economic and monetary union. The circumstances surrounding the debt crisis are aggravating the conduct of the Eurosystem's common monetary policy, which is geared toward maintaining price stability in the euro area as a whole.

\section{Heterogeneity as a Challenge for Monetary Policy}

One of the aggravating factors is heterogeneity in terms of growth, inflation, and competitiveness. With regard to the euro-area countries' economic performance, we are currently observing a widening divergence. Broadly speaking, there is a considerable growth gap between the core and the periphery, or to put it more precisely, some peripheral countries of the euro area.

In my view, the economic heterogeneity of the euro area is a non-issue. Why should heterogeneity be a problem for the single monetary policy? After all, the dispersion of growth rates, as measured by the weighted standard deviations of quarterly growth rates, is not significantly greater than in the first years of the EMU. With regard to inflation variance, we now see even lower values than then. Furthermore, the U.S. economy is characterized by considerable heterogeneity, too, and that does not impede the Federal Reserve's monetary policy, either. And in much the same way as the Federal Open Market Committee is focused on the United States as a whole, the Governing Council of the European Central Bank must take a euro-area-wide perspective: While national developments have to be taken into consideration, monetary policy cannot be tailored to the specific needs of individual member states.

The real problem with heterogeneity-and that is a concern to me-is that a number of countries have obviously failed to meet the obligations and requirements of a currency union. The persistent problems of countries in refinancing their debt are only the symptoms of the problems, not the problem itself. The financial crisis 
has revealed unsustainable developments in some member countries- developments that were already in existence before the crisis: too much public spending, unproductive use of capital inflows, loss of competitiveness. These were just some of the shortcomings that had been carelessly neglected, not least by the financial markets. Painful adjustment processes, including structural reform and budget consolidation, are essential to restore the ability of the countries concerned to live up to the demands of the single monetary policy.

\section{Fiscal Stabilization Measures Were Necessary but They Undermined the Basic Founding Principles of the EMU}

Ensuring financial stability in the euro area required and justified fiscal aid for Greece and the establishment of a temporary stabilization mechanism. Nevertheless, these particular measures have undermined the foundations of the EMU.

The establishment of the EMU was based on principles deemed necessary to make the euro a stable currency. According to the principle of subsidiarity, economic policies other than monetary policy remain the responsibility of national governments. With regard to fiscal policy, rules and institutional arrangements were established to ensure sound fiscal policies in the member states. Furthermore, a "no-bailout" clause stipulated the national responsibility of each country for repaying its own public debt.

Rules for sound public finances are of particular importance in a monetary union since the incentives for excessive borrowing are even greater in a monetary union than they are anyway. Excessive borrowing can also place a strain on the conduct of a stability-oriented monetary policy. Unsound public finances are the Achilles' heel of a monetary union of independent states.

Purchases of government bonds for monetary policy purposes, for example, harbor the risk of blurring the boundaries between monetary and fiscal policy, particularly given high government deficits and debt levels. Such actions might harm the credibility of monetary policy. A little earlier,
I said that monetary policy must remain focused on price stability and should not be overburdened with other objectives. This principle applies not only with respect to financial stability, but also fiscal policy.

During the financial crisis, the Eurosystemlike the central banks of other major economic regions-took unconventional monetary policy measures on an unprecedented scale. The ample provision of liquidity was effective in offsetting the consequences of the abrupt decline in market liquidity, in maintaining monetary policy transmission, and, ultimately, in helping to prevent the real economy from sliding into a prolonged depression. On the other hand, unlimited provision of central bank liquidity to banks without a sustainable business model cannot be a long-run solution. Again, monetary policy should not act as a substitute for tasks of other policy areas. In particular, monetary policy should not and cannot persistently replace the repair of banks' balance sheets. The phasing-out of non-standard measures has to be continued; the objective is to return to the pre-crisis operational framework which has proven its effectiveness and flexibility during the crisis.

\section{Economic Governance in the Euro Area Needs Reform}

Since the fiscal stabilization measures in favor of euro-area peripheral countries have undermined the basic principles of the EMU, it is obvious that there has to be a fundamental and far-reaching reform of economic governance in the euro area. First, the European leaders agreed that the fiscal rules must be tightened since their application in practice had proven too weak.

Second, they agreed that macroeconomic imbalances should be addressed earlier and more effectively. The crisis demonstrated that sound public finances are a necessary, but not sufficient, condition for financial and economic stability. Ireland, for instance, was among the least-indebted countries of the euro area before the crisis erupted. Finally, the leaders agreed to establish a permanent stabilization mechanism since it is an illusion to believe that a reform of economic governance 
might prevent the reoccurrence of fiscal crises in the future.

In March, the leaders agreed on what they view as a comprehensive package. Its measures certainly represent a step in the right direction, but they are not a "quantum leap towards strengthening the institutional framework of EMU" (European Central Bank, 2010, p. 4), which is required to reinforce economic governance in the euro area. Ultimately, the future success of the EMU will hinge crucially on the member states' willingness to comply with the tighter set of rules.

\section{CONCLUSION}

Tomorrow, it will be 17 years ago to the day since Helmut Schlesinger, one of my predecessors as president of the Bundesbank, gave the Eighth Homer Jones Memorial Lecture. In his speech, "On the Way to a New Monetary Union: The European Union," he explained the historic dispute between "monetarists" and "economists" (Schlesinger, 1994). In the particular context of European monetary integration, these terms had a totally different meaning than our general understanding. "'Monetarists,"” he explained, "believed that monetary integration has to start first and that economic and political integration would follow." "'Economists,"” however, "believed that economic convergence between the national economies must occur before...a monetary union."

The "monetarists" prevailed, but they erred in their belief that the introduction of the single currency would automatically act as a locomotive for the political union of Europe. There is no political union so far and there is little expectation that this might change significantly in the foreseeable future. Therefore, national executive and legislative branches will remain responsible for economic and fiscal policies over the medium to long term. Intergovernmental fiscal transfers beyond the rather moderate and earmarked payments from the European Union budget (approximately 1 percent of gross national product) are hardly acceptable; overburdening the financial solidarity of the people might jeopardize the idea of European integration.

The "economists," on the other hand, had a point in demanding more economic convergence. Their worries were, by the way, taken into account by the implementation of convergence criteria that must be fulfilled before a country can join the euro area. The underlying problem of the current crisis is, however, not a lack of convergence ex ante or heterogeneity per se; rather, it is the lack of willingness on the part of a number of member states to meet the requirements of the membership in a monetary union. If they fail to correct these deficiencies swiftly and thoroughly, stability-oriented monetary policy in the EMU will become increasingly difficult, all the more so as monetary policy has been profoundly challenged by the financial crisis.

The major lessons that central bankers in the euro area and elsewhere should take to heart are the following: First, monetary policy has to consider the implications of financial instability for price stability; monetary and credit aggregates can provide helpful information in this regard. Second, since the policy rate remains too blunt a tool to tackle financial imbalances, the objective of financial stability requires its own, macroprudential set of tools, whereas maintaining price stability should remain the primary objective of monetary policy. Third, price stability should continue to be seen as a stable and low inflation rate. Finally, without stability-oriented prudent fiscal policy, it will be increasingly difficult for monetary policy to ensure price stability at low interest rates. 


\section{REFERENCES}

Angelini, Paolo; Neri, Stefano and Panetta, Fabio. "Grafting Macroprudential Policies in a Macroeconomic Framework: Choice of Optimal Instruments and Interaction with Monetary Policy.” Unpublished manuscript, Banca d'Italia, March 5, 2010; www.bis.org/repofficepubl/hkimr201007.15.pdf.

Bank for International Settlements. 80th Annual Report. Basel, Switzerland: Bank for International Settlements, 2010; www.bis.org/publ/arpdf/ar2010e.pdf.

Basel Committee on Banking Supervision. "BASEL III: A Global Regulatory Framework for More Resilient Banks and Banking Systems.” Basel, Switzerland: Bank for International Settlements, December 2010; www.bundesbank.de/download/bankenaufsicht/pdf/basel3 capital rules.pdf.

Bean, Charles; Paustian, Matthias; Penalver, Adrian and Taylor, Tim. "After the Fall," in Macroeconomic Challenges: The Decade Ahead. Proceedings of the 2010 Jackson Hole Economic Policy Symposium, Jackson Hole, Wyoming, August 26-28, 2010. Kansas City, MO: Federal Reserve Bank of Kansas City, 2010; www.kansascityfed.org/publicat/sympos/2010/bean-paper.pdf.

Beau, Denis; Clerc, Laurent and Mojon, Benoît. "Macro-Prudential Policy and the Conduct of Monetary Policy." Unpublished manuscript, Banque de France, January 2011; www.benoitmojon.com/pdf/Beau-Clerc-Mojon.pdf.

Blanchard, Olivier J.; Dell’Ariccia, Giovanni and Mauro, Paolo. “Rethinking Macroeconomic Policy.” Journal of Money, Credit, and Banking, September 2010, 42(Suppl. 1), pp. 199-215.

Christensen, Ian; Meh, Césaire and Moran, Kevin. "Bank Leverage Regulation and Macroeconomic Dynamics." Unpublished manuscript, Bank of Canada, 2011.

Committee on the Global Financial System. "Macroprudential Instruments and Frameworks: A Stocktaking of Issues and Experiences." CGFS Paper No. 38, Committee on the Global Financial System, Bank for International Settlements, May 2010; www.bis.org/publ/cgfs38.pdf.

Deutsche Bundesbank. "Price-Level Targeting as a Monetary Policy Strategy.” Monthly Report, January 2011a, pp 31-45; www.bundesbank.de/download/volkswirtschaft/mba/2010/201001mba en price.pdf.

Deutsche Bundesbank. "Approaches to the Measurement and Macroprudential Treatment of Systemic Risk." Monthly Report, March 2011b, pp. 37-52.

Deutsche Bundesbank. "The Implications of the Financial Crisis for Monetary Policy.” Monthly Report, March 2011c, pp. 53-68.

Eggertsson, Gauti B. and Woodford, Michael. "The Zero Bound on Interest Rates and Optimal Monetary Policy.” Brookings Papers on Economic Activity, 2003, 1, pp. 139-211; www.newyorkfed.org/research/economists/eggertsson/BrookingsPaper.pdf.

European Central Bank. "Reinforcing Economic Governance in the Euro Area.” European Central Bank, June 20, 2010; www.ecb.int/pub/pdf/other/reinforcingeconomicgovernanceintheeuroareaen.pdf.

Galati, Gabriele and Moessner, Richhild. "Macroprudential Policy: A Literature Review.” BIS Working Paper No. 337. Bank for International Settlements, February 2011, www.bis.org/publ/work337.pdf. 


\section{Weber}

Gerberding, Christina; Gerke, Rafael and Hammermann, Felix. "Price-Level Targeting When There Is Price-Level Drift.” Discussion Paper, Series 1, No. 23/2010; Deutsche Bundesbank Research Centre, December 30, 2010; www.bundesbank.de/download/volkswirtschaft/dkp/2010/201023dkp.pdf.

Papademos, Lucas D. and Stark, Jürgen, eds. Enhancing Monetary Analysis. Frankfurt, Germany: European Central Bank, 2010.

Schlesinger, Helmut. "On the Way to a New Monetary Union: The European Monetary Union.” Federal Reserve Bank of St. Louis Review, May/June 1994, 76(3), pp. 3-10;

http://research.stlouisfed.org/publications/review/94/05/Union May Jun1994.pdf.

Walsh, Carl. "The Future of Inflation Targeting.” Unpublished manuscript, University of California, Santa Cruz, September 2010; http://people.ucsc.edu/ walshc/MyPapers/walsh ace 20100927.pdf.

Weber, Axel A. "From Academic to Policy Maker.” BIS Review No. 56, June 2007; www.bis.org/review/r070601a.pdf.

Weber, Axel A. Comment on Jordi Galí, "The Monetary Pillar and the Great Financial Crisis,” in The Great Financial Crisis: Lessons for Financial Stability and Monetary Policy. A Colloquium in Honour of Lucas Papademos. Frankfurt, Germany: European Central Bank, May 20-21, 2010a.

Weber, Axel A. "Der IWF spielt mit dem Feuer (The IMF Is Playing with Fire).” Financial Times Deutschland, February 25, 2010b (available in German only); www.bundesbank.de/download/presse/publikationen/20100225 namensbeitrag weber.pdf.

Williams, John C. "Heeding Daedalus: Optimal Inflation and the Zero Lower Bound.” Brookings Papers on Economic Activity, Fall 2009, pp. 1-37. 